\title{
PERUBAHAN PERMUKIMAN PERDESAAN PESISIR KABUPATEN GUNUNG KIDUL DAERAH ISTIMEWA YOGYAKARTA TAHUN 1996-2003
}

\author{
Su Ritohardoyo \\ Fakultas Geografi Universitas Gadjah Mada, \\ Bulaksumur, Telp (0274) 902336, Telex: 25135 Yogyakarta \\ E-mail: s_ritohardoyo@yahoo.com
}

\begin{abstract}
One of the impacts of coastal region development is settlement change. Because of that, this article presents a result of research about changing of settlement land area, house buildings, settlement facilities since 1996 up to 2003, and several factors which influence to the changing. This research was carried out in 20 karst villages borders on Indian Ocean so-called coastal villages in of Gunungkidul Regency as analysis units. Data analysis employs so-called secondary data analysis method, using Village Potentials Cencus (PODES) data were published in Statistics Central Bureau. Data analysis employs frequency, cross tabulations, and statistical analysis. Result of this research shows that as long as 1996 up to 2003 the settlement land area increases on $0.24 \%$ per annum on an average, while the bouse building number on $6.14 \%$ per annum. Spatially several coastal rural villages are near or as a tourism object or as a district office locations are higher developing than the others of coastal rural villages. It means that the development of tourism objects as long as 1996 up to 2003 has influenced the coastal rural settlement development. Generally, the development of coastal rural settlement is significantly also influenced by thirteen of physical and socio-economical factors $(R=0.903$; Sig. $=0.05$ ). In detail however, among the 13th of physical and socio-economical factors are only five factors significant influence to the development of coastal rural settlement. The 5 th factors are the average of place elevation, well number, propotion of agriculteral land area, household densty, and population density. Based on that findings in order to develope of coastal rural settlement especially in karst region, besides the development of tourism objects, the five factors should be taken in consideration.
\end{abstract}

Key words: Coastal Rural Settlement, Rural Settlement Change, Physical and Socio-economical Factors.

\section{PENDAHULUAN}

Hakekat perkembangan permukiman desa di setiap wilayah adalah perubahan, yang dapat terjadi secara terencana maupun secara tidak terencana. Hal ini berakibat pada perkembangan kuantitas dan kualitas permukiman bervariasi secara keruangan. Beberapa masalah perdesaan yang berkaitan dengan ruang wilayah antara lain belum serasinya perkembangan dan keterkaitan aktifitas pertanian dengan sektor lain dalam pengembangan wilayah sebagai satu kesatuan, masih banyaknya kerusakan lingkungan akibat konversi lahan, dan masih kurang layaknya kondisi lingkungan perumahan dan permukiman berserta sarana dan prasarana permukiman penduduknya (Pascione, 1984; Riyadi, 2000). Oleh karena itu, dalam usaha pengembangan permukiman desa perlu kajian variasi keruangan perubahan permukiman dan faktor-faktor pendukungnya.

Hal tersebut sejalan dengan kebijakan pengembangan permukiman di Indonesia yang menekankan dua prioritas (Dirjen Perumahan dan Permukiman, 2002). 
Pertama prioritas jenis kegiatan antara lain pembangunan dan pemeliharaan prasarana dan sarana pendukung permukiman, dan prioritas kedua adalah lokasi antara lain pembangunan di pulau-pulau kecil, dan pengembangan kualitas permukiman di wilayah perdesaan pesisir. Kebijakan pengembangan permukiman tersebut mendasari pentingnya penelitian tentang perkembangan permukiman, khususnya perkembangan permukiman perdesaan kepesisiran. Hal ini mengingat peran wilayah kepesisiran bagi kesejahteraan penduduk menurut sebagai ruang tempat kehidupan penduduk, baik kehidupan sosial-budaya maupun kehidupan sosial-ekonomi.

Manning and Sweet (1993) berpendapat bahwa di balik peran wilayah pesisir sebagai ruang tempat kehidupan sosial ekonomi dan sosial budaya penduduk, dalam pengembangan potensi wilayah kepesisiran sering terjadi tumpang tindih. Kehidupan sosial budaya penduduk pesisir dengan berbagai kegiatannya, di satu sisi memanfaatkan lahan permukiman dan sarana-prasarana fisik kegiatannya, di sisi lain memanfaatkan lahan untuk penghasil bahan pangan, tidak jarang menjadi masalah dalam pengelolaan wilayah kepesisiran. Dua kebutuhan sumberdaya lahan bagi penduduk ini selalu berbenturan, ketika salah satu pemenuhan kebutuhan lahan lebih dominan dari pada kebutuhan lahan lainnya (Mather, 1986). Kebutuhan lahan berkaitan erat dengan lingkungan wilayah setempat, baik bersifat saling bergantung, maupun bersifat saling berpengaruh.

Keterkaitan antara kebutuhan dan pemanfaatan lahan dengan aspek wilayah pesisir (Ritohardoyo, 1991) tampak dalam aplikasinya untuk konservasi lahan, dan dasar pengembangan wilayah. Pemenuhan kebutuhan lahan yang tidak mengindahkan norma pelestarian, dapat berakibat pada terjadinya kerusakan ekosistem pesisir, yang sangat merugikan kehidupan penduduk. Oleh karenanya, pengembangan perdesaan pesisir merupakan usaha yang bersifat strategis yang sangat diperlukan. Pengembangan perdesaan pesisir sebagai permukiman penduduk berkaitan erat dengan pemecahan masalah-masalah perdesaan saat kini dan masa mendatang, memerlukan dasar informasi dan data perkembangan setiap desa.

Uraian di atas mendasari perlunya penelitian perubahan permukiman perdesaan di wilayah pesisir Kabupaten Gunungkidul Daerah Istimewa Yogyakarta, yang memiliki karakteristik wilayah pesisir antara lain (Tim Fak.Geografi UGM, 2003): (1) secara fisik seluruh daerahnya bertopografi karst, (2) dalam dua dasa warsa terakhir pemanfaatan sebagian ekosistem wilayah pesisir dikembangkan sebagai obyek-obyek wisata dan tempat usaha perikanan laut. Hal itu telah berdampak pada aktifitas sebagian penduduk, salah satunya pergeseran matapencaharian dari petani ke nelayan (Ritohardoyo, 2002). Pengembangan itu berperan besar terhadap perubahan-perubahan permukiman maupun pertanian yang sudah sejak lama berada di kawasan ini. Oleh karena itu, penelitian dilaksanakan dengan tekanan tujuan mengungkap (1) perubahan permukiman desa di wilayah pesisir dari tahun 1996 hingga 2003, baik luas lahan permukiman, jumlah bangunan rumah, maupun fasilitas permukiman; (2) pola persebaran perubahan permukiman di wilayah pesisir; dan (3) besarnya pengaruh perubahan setiap komponen wilayah terhadap perubahan permukiman desa pesisir.

\section{METODE PENELITIAN}

Penelitian ini bersifat deskriptif analitis menggunakan metode analisis data 
sekunder. Untuk memperoleh fenomena persebaran, digunakan pendekatan analisis keruangan. Satuan administratif desa pesisir adalah desa yang berbatasan langsung dengan Samudera Hindia digunakan sebagai unit analisis, sebanyak 20 desa yang merupakan bagian-bagian dari 6 daerah kecamatan. Variabel dan data penelitian secara umum terdiri dari tujuh bagian, yaitu aspek geografi, demografi, penggunaan lahan, fisik lahan, pertanian, ekonomi, dan kebijakan pembangunan. Sebagian besar data sekunder diperoleh dari Potensi Desa (PODES) tahun 1996 dan 2003 dan dari instansi setempat. Di samping itu juga dilakukan pengumpulan primer dari observasi lapangan.

Analisa data menggunakan cara penilaian berbagai komponen pembentuk permukiman desa pesisir, berdasar prinsip teknik analisis kuantitatif dan kuantifikasi data kualitatif. Teknik kuantifikasi data kualitatif menekankan pada penilaian data untuk memperoleh nilai indeks komposit. Potensi desa tahun 1996 dan tahun 2003, dianalisis besarnya nilai indeks komposit beberapa potensi sumberdaya fisik, sumberdaya biotik, dan potensi sumberdaya budaya penduduk. Analisis tingkat perkembangan setiap potensi sumberdaya setiap desa pesisir; dengan cara menghitung selisih nilai-nilai indeks komposit. Hasil pengurangan data periode tahun 2003 dengan data tahun 1996 dapat memberikan kemungkinan nilai negatip dan positip, yang bermakna perkembangan menurun atau meningkat.

Setiap perkembangan baik peningkatan ataupun penurunan nilai perkembangan dianalisis secara spasial, sehingga dapat ditunjukkan pola persebaran setiap gejala pola perkembangan baik bersifat negatip dan positip. Pengaruh tingkat perkembangan faktor-faktor wilayah terhadap tingkat perkembangan permukiman desa pesisir, dianalisis berdasar uji statistik regresi ganda dari variabel yang telah dinilai secara kuantitatif berwujud indeks komposit. Analisis hasil komprehensif keterkaitan antara variabel penelitian dengan konteks regional, termasuk kebijakan pembangunan dan prediksi perkembangannya, menggunakan analisis deskriptif kualitaif.

\section{HASIL PENELITIAN DAN PEMBA- HASAN}

\section{Kondisi Wilayah Permukiman Desa Pesisir}

Wilayah pesisir Kabupaten Gunung Kidul secara keruangan terletak di Pegunungan Sewu, secara administratif terdiri atas 20 desa yang merupakan bagianbagian daerah dari enam kecamatan. Luas daerah secara keseluruhan sebesar 33.306,7 hektar atau $333,07 \mathrm{~km}^{2}$, yang terbagi menjadi 493 Rukun Warga (RW) atau 1.049 Rukun Tetangga (RT). Bentuk wilayah memanjang pantai dari Desa Girijati hingga Desa Songbanyu (Tabel 1; Lampiran Gambar 1.). Sebagian besar daerah ini memiliki elevasi antara $0-500$ meter dari permukaan laut (mdpal), namun keberadaan pedusunan pada ketinggian antara 200 - 500 mdpal (BPS. Kab. Gunungkidul, 2004). Kemiringan lereng daerah sebagian besar curam $(\geq 20 \%)$ dan sebagian lagi landai $(<20 \%)$. Hal ini berkaitan erat dengan kondisi geomorfologis wilayah yang merupakan pantai dengan topografi Karst.

Sebagian besar perdesaan pesisir ini termasuk daerah Inti Karst, dengan pantai yang secara tipologis terdiri dari tipe pantai struktural dan tipe pantai erosi gelombang (King, 1972 dalam Raharjo, 2003). Pantai 


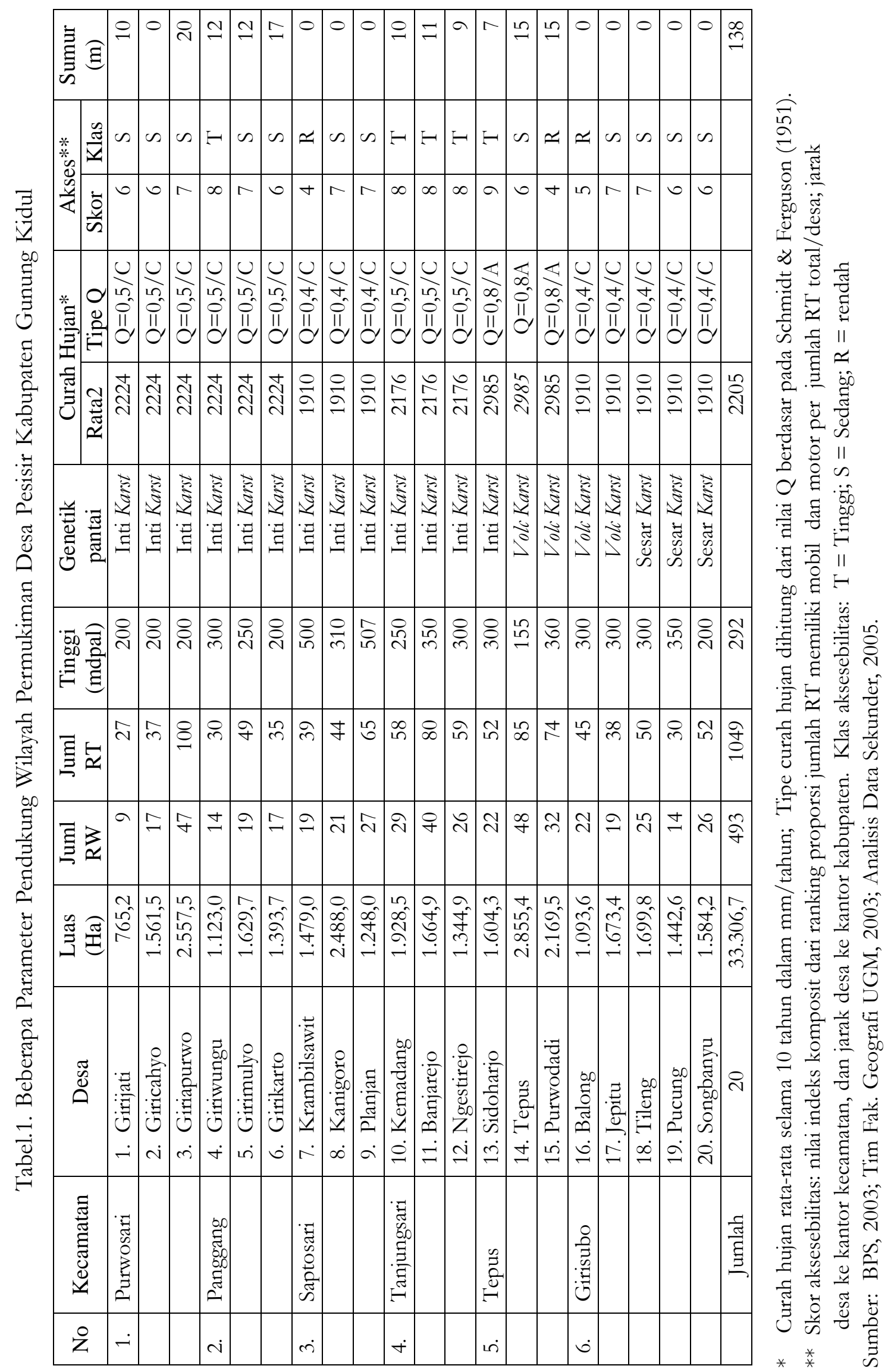


tipe struktural berkembang akibat pengaruh erosi daratan diikuti oleh proses inundasi, yang mencakup 13 desa di sebagian Daerah Kecamatan Purwosari, Panggang, Saptosari, Tanjungsari, dan Tepus; (Tabel 1.). Sebagian lagi (7 desa) termasuk daerah Non Karst, terutama di Kecamatan Girisubo; dimana sebagian material batuannya adalah Volcanic-Karst, dan Sesar-Karst.

Ditinjau dari aspek klimatologis wilayah ini menghadapi kendala, dimana curah hujan tahunan rata-rata di setiap desa bervariasi, antara $1910 \mathrm{~mm} /$ tahun (rendah) di perdesaan Kecamatan Girisubo dan Saptosari, hingga $2985 \mathrm{~mm} /$ tahun (tinggi) di perdesaan Kecamatan Tepus. Tipe curah hujan (Q) berdasarkan pada SchmidtFerguson (1951) daerah ini didominasi tipe C, kecuali di Kecamatan Tepus termasuk tipe A (Tabel 1.). Meskipun curah hujan tahunan rata-rata relatif tinggi $(2205 \mathrm{~mm} /$ tahun), namun tidak tersebar merata sepanjang tahun, sehingga sebagian besar desa sering mengalami bencana kekeringan.

Keberadaan air telaga (danau karst) bersifat terbatas pada musim kemarau kering; dan kualitas air kurang memenuhi baku mutu air bersih. Meskipun terdukung oleh curah hujan, air hujan yang jatuh meresap melalui rongga-rongga dan membentuk sungai bawah tanah (McDonald \& Partners (1984). Hal ini menyebabkan air permukaan di perdesaan pesisir sulit ditemukan, sehingga telaga yang berair musiman dimanfaatkan penduduk secara multi purpose. Potensi airtanah cukup besar, tetapi keberadaannya sangat dalam. Di antara 20 desa pesisir di daerah penelitian hampir separuh tidak memiliki sumur (Tabel 1.). Di beberapa desa yang memiliki sumur kedalamannya lebih dari 15 meter. Artinya, untuk memperoleh air di daerah ini menghadapi kendala fisik dan kendala ekonomi untuk biaya teknologi.

Meskipun seluruh desa pesisir berada pada topografi Karst yang ekstrim dengan berbagai kendala fisik yang dihadapi, namun hubungan baik antar desa, kecamatan, kabupaten, bahkan antar propinsi cukup lancar. Di antara 20 desa pesisir ini sebagian besar (12 desa) memiliki tingkat aksesebilitas sedang, 5 desa pada tingkat tinggi, dan hanya 3 desa dengan aksesebilitas rendah (Tabel 1.). Hal ini menurut Mut'ali (2003) ketersediaan jaringan jalan penghubung wilayah perdesaan pesisir karst dengan daerah lain berakibat pada hubungan tingkat lokal dan tingkat regional makin lancar. Tingkat aksesebilitas ini mendukung dinamika penduduk dan permukimannya.

\section{Perubahan Permukiman Perdesaan Pesisir}

\section{Perubahan Luas Lahan Permu- kiman}

Kondisi lahan Pegunungan Karst Kabupaten Gunungkidul sudah sejak lama mengalami perubahan. Hal ini dapat ditunjukkan dari aspek bentuk penggunaan lahan, seperti yang dilaporkan Junghun (1857) dan Nibbering (1990) mengungkap bahwa sejak adanya okupasi penduduk di daerah ini baik bermukim maupun bercocoktanam pertanian, Gunung Sewu yang dahulunya merupakan mixed evergreen rain forest, telah mengalami banyak perubahan biofisik. Perubahan terjadi pada luas lahan hutan dan keragaman serta jenis tumbuhan hutan baik di bagian pedalaman maupun di pesisir. Artinya, sejak keberadaan permukiman penduduk menempati sebagian lahan kawasan karst, perubahan di daerah pesisir mulai terjadi perubahan penggunaan lahan baik untuk permukiman dan pertanian. 
Lahan perdesaan pesisir dewasa ini terdiri terdiri dari (1) dataran aluvial, karst, dan lembah karst, hanya sesuai untuk tanaman musiman; dan (2) perbukitan karst, kompleks doline dan kubah karst, tidak sesuai untuk usaha produksi pertanian (Tim Fak. Geografi UGM, 2003). Kenyataanmya, perbukitan dan kubah karst telah dimanfaatkan penduduk untuk pertanian sehingga menjadi 'gundhul'. Perubahan setiap penggunaan lahan antar desa bervariasi, baik ukuran luas, sifat perubahannya, serta akibat pada luasnya lahan kritis (Tabel 2.). Perubahan luas pekarangan dan bangunan ada yang meningkat, namun juga terdapat desa dengan luas pekarangan dan bangunan relatif tetap, bahkan ada yang mengalami pengurangan. Perluasan pekarangan dan bangunan terbesar terjadi di Desa Girijati (3,35\%), akibat pengaruh perkembangan obyek wisata Parangtritis, dimana lahan-lahan perbukitan yang berbatasan langsung dengan obyek wisata tersebut, banyak dimanfaatkan untuk penginapan dan permukiman.

Perluasan pekarangan di Desa Sidoharjo sebagai akibat fungsi desa tersebut sebagai pusat ibukota Kecamatan Tepus. Selain itu, jumlah penduduk datang lebih banyak dari pada yang pergi di beberapa desa setelah tahun 1999 sebagai dampak krisis ekonomi. Sebagian migran yang kembali ke desa-desa tersebut ketika krisis ekonomi terjadi membangun rumah. Berkurangnya luas perkarangan selama lima tahun terakhir, terjadi sebagai akibat ditinggalkan sebagian penduduk pindah ke kampung lain, dan yang lebih banyak migrasi ke luar kabupaten dan transmigrasi. Antara tahun 1996-1998 pengiriman transmigran dari Desa Pucung, Jepitu, dan Balong sekitar 145 rumahtangga; sedangkan di Giriwungu dan Ngestiharjo sekitar
79 rumahtangga. Lahan pekarangan dan bangunan mereka jual, oleh pembelinya dimanfaatkan sebagai lahan pertanian tegal atau kebun campuran.

Akibat perubahan penggunaan lahan di setiap desa tersebut terjadi perubahan luas lahan kritis. Peningkatan luas lahan kritis di antara 20 desa pesisir hanya terjadi di Desa Giricahyo dan Giriwungu sebesar $1,6 \%$ dan 5,06\% dari seluruh luas desa. Lahan kritis di sebagian besar desa semakin sempit, seperti di desa-desa Krambilsawit dan Pucung mengalami pengurangan lahan kritis hampir 40 persen dari luas setiap desa. Semakin luas pengurangan lahan kritis di sebagian besar desa peisisir, merupakan salah satu indikator bahwa kondisi permukiman desa-desa tersebut berubah semakin baik.

\section{Perubahan Kondisi Perumahan}

Tingkat perkembangan rata-rata persentase jumlah bangunan rumah permanen sebesar 42,97 persen selama 6 tahun atau 7,16 persen per tahun. Peningkatan kualitas bangunan rumah secara keruangan antar desa bervariasi, peningkatan yang melebihi 50 persen selama 6 tahun terjadi di sembilan desa, lima desa berada di perdesaan pesisir selatan bagian barat; sedangkan empat desa pesisir lainnya berada di bagian timur daerah penelitian (Tabel 2. dan Lampiran Gambar .2.). Lokasi perkembangan bangunan rumah perdesaan pesisir tersebut, tampaknya berkaitan dengan perkembangan daerah secara umum, baik pengembangan pemekaran daerah administratif, obyek-obyek wisata pantai, maupun daerah asal migran yang relatif kritis secara fisik.

Pemekaran daerah administratif yang tadinya satu kecamatan menjadi dua 


\begin{tabular}{|c|c|c|c|c|c|c|c|c|c|c|c|c|c|c|c|c|c|c|c|c|c|}
\hline 氙 & $m$ & + & $\nabla$ & + & + & + & $\nabla$ & + & + & $m$ & $\nabla$ & 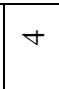 & $\infty$ & $\nabla$ & $\infty$ & + & + & $\nabla$ & + & $\nabla$ & \\
\hline 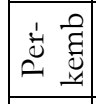 & $m$ & $m$ & $m$ & $v$ & $N$ & - & $N$ & $N$ & $\sim$ & $n$ & - & - & $\infty$ & $\sim$ & $\sim$ & $N$ & -1 & - & $\sim$ & - & \\
\hline 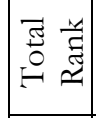 & : & $\infty$ & t & 守 & $\vec{n}$ & 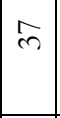 & in & in & $\overrightarrow{i n}$ & \llcorner & q & $\vec{n}$ & 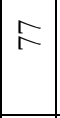 & $\mid \begin{array}{l}n \\
8 \\
8\end{array}$ & in & $\vec{n}$ & $\infty$ & $\hat{n}$ & $\vec{\sigma}$ & $\begin{array}{l}\text { no } \\
\text { of }\end{array}$ & \\
\hline 紫出 & \pm & $\stackrel{0}{-}$ & 2 & $r$ & $\exists$ & $\sim$ & 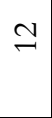 & $\stackrel{\infty}{\sim}$ & in & $\stackrel{2}{2}$ & $m$ & + & $\approx$ & $\because$ & 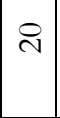 & ○ & 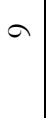 & - & $\Xi$ & $\infty$ & 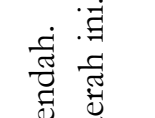 \\
\hline 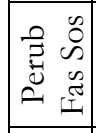 & $\begin{array}{l}\tilde{\theta} \\
\hat{i}\end{array}$ & $\stackrel{\hat{n}}{\rightarrow}$ & $\stackrel{\hat{n}}{\sim}$ & $\cong$ & $\stackrel{+}{\leftrightarrow}$ & $\left|\begin{array}{l}\infty \\
0 \\
0^{n}\end{array}\right|$ & $\stackrel{\Omega}{n}$ & $\begin{array}{l}\hat{n} \\
\hat{n}\end{array}$ & $\mid \begin{array}{l}0 \\
\stackrel{2}{0}\end{array}$ & $\vec{v}$ & $\begin{array}{l}\hat{A} \\
\hat{0}\end{array}$ & $\sigma_{0}$ & $\left|\begin{array}{c}0 \\
⿱ \\
m \\
m\end{array}\right|$ & \begin{tabular}{|l}
$\vec{w}$ \\
$\vec{v}$
\end{tabular} \mid & $\stackrel{m}{f}$ & $\Rightarrow$ & 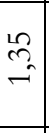 & $\begin{array}{l}\overrightarrow{\hat{N}} \\
\hat{0}\end{array}$ & $\begin{array}{l}\infty \\
\stackrel{i}{i}\end{array}$ & $\stackrel{\sim}{\sim}$ & 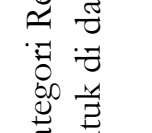 \\
\hline 类 & $\stackrel{2}{-1}$ & $\Xi$ & $\approx$ & $\stackrel{\infty}{-}$ & in & $\sim$ & $a$ & $r$ & $\stackrel{0}{\circ}$ & $\stackrel{\stackrel{n}{\sim}}{\rightarrow}$ & $\approx$ & $\infty$ & 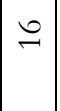 & $\Xi$ & $\exists$ & 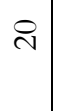 & $\nabla$ & 0 & $m$ & - & 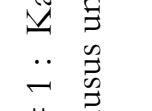 \\
\hline 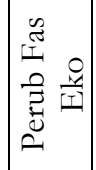 & $\Leftrightarrow$ & $\left|\begin{array}{l}a \\
\hat{i} \\
i\end{array}\right|$ & $\stackrel{\sim}{-}$ & $\stackrel{\mathfrak{F}}{i}$ & $\stackrel{\vec{\sigma}}{-}$ & $\left|\begin{array}{l}\hat{\mathrm{v}} \\
\hat{0}\end{array}\right|$ & 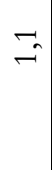 & 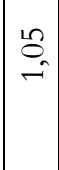 & $\stackrel{\sim}{\sim}$ & $\begin{array}{l}t \\
0 \\
i\end{array}$ & $\begin{array}{l}\infty \\
i \\
\hat{N}\end{array}$ & $\hat{\sigma}_{-}$ & $\left|\begin{array}{l}\hat{b} \\
i \\
i\end{array}\right|$ & $\left|\begin{array}{c}\mathfrak{v} \\
\hat{i}\end{array}\right|$ & $\left|\begin{array}{l}0 \\
- \\
-\end{array}\right|$ & $\begin{array}{c}\tilde{m} \\
\tilde{m}\end{array}$ & - & $\stackrel{\tilde{c}}{\rightarrow}$ & $\tilde{0}^{2}$ & $\tilde{o}_{0}$ & 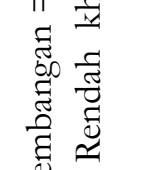 \\
\hline 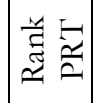 & 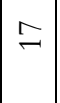 & 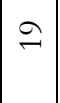 & \pm & - & $n$ & $r$ & $\stackrel{10}{\sim}$ & 0 & 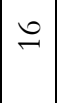 & $a$ & $v$ & $\infty$ & $\stackrel{0}{-}$ & $\exists$ & in & $\nabla$ & 2 & 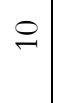 & ิ & 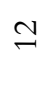 & 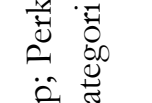 \\
\hline 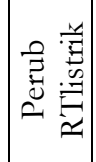 & $\mid \begin{array}{c}+ \\
\hat{n} \\
\hat{\imath}\end{array}$ & $\begin{array}{l}q \\
\hat{q} \\
\hat{i}\end{array}$ & 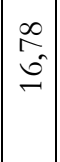 & 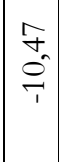 & fo & $\stackrel{10}{i}$ & $\stackrel{+}{\stackrel{\sigma}{\sigma}}$ & $\stackrel{\substack{1 \\
-}}{-}$ & $\begin{array}{c}\hat{N} \\
\hat{\sim} \\
\sim\end{array}$ & $\stackrel{?}{\stackrel{?}{r}}$ & $\begin{array}{l}\infty \\
\stackrel{\infty}{0} \\
\infty 0^{0}\end{array}$ & 年 & $\overrightarrow{\vec{v}}$ & $\stackrel{\sim}{\sim}$ & 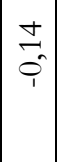 & $\stackrel{\vec{\imath}}{\hat{\imath}}$ & $\underset{\hat{\sigma}}{\sigma}$ & $\hat{\hat{\sigma}^{\prime}}$ & 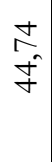 & $\vec{m}$ & 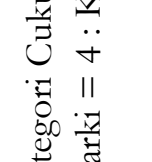 \\
\hline 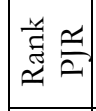 & $\sim$ & \pm & $\approx$ & $\stackrel{\infty}{-}$ & 0 & 10 & - & in & $m$ & $a$ & + & 0 & $\sim$ & $\stackrel{2}{-2}$ & $\infty$ & 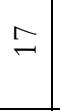 & 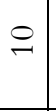 & $\exists$ & $\stackrel{\sim}{\sim}$ & $\approx$ & $\begin{array}{c}\dot{u} \\
\ddot{\sim} \\
\ddot{\sim}\end{array}$ \\
\hline 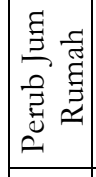 & $\begin{array}{l}n \\
n \\
r\end{array}$ & $\left|\begin{array}{c}+ \\
2 \\
2 \\
n \\
n\end{array}\right|$ & 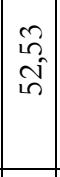 & \begin{tabular}{|l|}
$\overrightarrow{\hat{n}}$ \\
$\hat{R}$
\end{tabular} & $\begin{array}{l}\hat{2} \\
\hat{n} \\
\hat{\sigma}\end{array}$ & $\left|\begin{array}{c}f \\
\infty \\
\infty \\
n \\
i n\end{array}\right|$ & $\begin{array}{l}\stackrel{2}{\mathrm{~s}} \\
\stackrel{\mathrm{s}}{2}\end{array}$ & $\begin{array}{l}\infty \\
\stackrel{0}{2}\end{array}$ & $\mid \begin{array}{l}0 \\
1 \\
\mathfrak{d} \\
-1\end{array}$ & 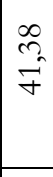 & $\begin{array}{l}\infty \\
\hat{\imath} \\
\mathfrak{y}\end{array}$ & $\begin{array}{l}0 \\
0 \\
+ \\
d\end{array}$ & $\left|\begin{array}{c}\vec{b} \\
\hat{m}\end{array}\right|$ & $\left|\begin{array}{c}\infty \\
i \\
\hat{n} \\
i n\end{array}\right|$ & $\left|\begin{array}{l}m \\
\stackrel{f}{n} \\
\tilde{m}\end{array}\right|$ & 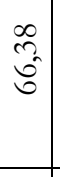 & $\begin{array}{l}\stackrel{2}{0} \\
\stackrel{n}{f}\end{array}$ & $\begin{array}{l}\grave{N} \\
\stackrel{+}{f}\end{array}$ & $\begin{array}{l}n \\
\infty \\
\infty \\
\infty\end{array}$ & $\begin{array}{l}\stackrel{2}{2} \\
2\end{array}$ & 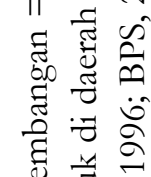 \\
\hline 竭至 & $\stackrel{\sim}{\circ}$ & $\stackrel{\infty}{\sim}$ & $\stackrel{2}{-1}$ & $m$ & 0 & $\exists$ & $\stackrel{20}{\rightarrow}$ & \pm & 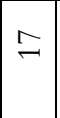 & $\infty$ & $\stackrel{\sim}{\sim}$ & in & $\approx$ & $\left|\begin{array}{l}10 \\
0 \\
0\end{array}\right|$ & 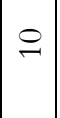 & + & $v$ & $a$ & - & $\overbrace{0}^{n}$ & 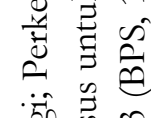 \\
\hline 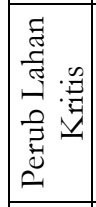 & $\overrightarrow{\vec{m}_{1}}$ & 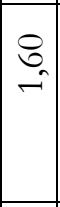 & $\begin{array}{c}m \\
\tilde{\alpha} \\
\infty \\
1\end{array} \mid$ & $\begin{array}{c}8 \\
\vdots \\
i n\end{array}$ & 旾 & $\left|\begin{array}{c}m \\
\infty \\
i \\
i\end{array}\right|$ & $\begin{array}{l}\hat{N} \\
\stackrel{m}{q}\end{array}$ & $\begin{array}{l}\vec{n} \\
\infty \\
1\end{array}$ & 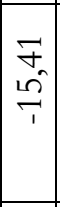 & 足 & 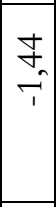 & $\begin{array}{l}+ \\
0 \\
0 \\
0 \\
0\end{array}$ & $\left|\begin{array}{c}0 \\
0 \\
-1 \\
i\end{array}\right|$ & $\begin{array}{l}\vec{F} \\
\vec{f}_{1}\end{array}$ & $\left|\begin{array}{l}2 \\
\hat{\sigma} \\
\hat{1}\end{array}\right|$ & $\begin{array}{c}\bar{\sigma} \\
\hat{0}\end{array}$ & $\begin{array}{l}2 \\
\text { மे }\end{array}$ & $\begin{array}{l}8 \\
8 \\
0 \\
-1\end{array}$ & $\begin{array}{l}\tilde{n} \\
\infty \\
\tilde{r}\end{array}$ & ? & 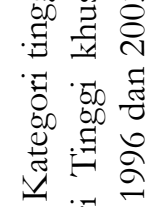 \\
\hline 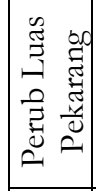 & $\left|\begin{array}{c}n \\
m \\
m\end{array}\right|$ & $\begin{array}{l}\mathfrak{y} \\
\tilde{0}\end{array}$ & $\mid \begin{array}{l}\mathfrak{N} \\
\tilde{0}\end{array}$ & $\mid$\begin{tabular}{l}
$\infty$ \\
\multirow{1}{1}{} \\
0 \\
1
\end{tabular} & ? & 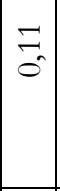 & ڤે & ते & $\mid \begin{array}{c} \pm \\
\tilde{0} \\
0\end{array}$ & $\tilde{\sigma}_{0}$ & $\stackrel{2}{\approx}$ & $\mid \begin{array}{l}\overrightarrow{0} \\
0 \\
0\end{array}$ & $\left|\begin{array}{c}\hat{n} \\
\hat{0}\end{array}\right|$ & $\theta_{0}$ & $\mid \begin{array}{l}0 \\
0 \\
0\end{array}$ & $\vec{i}$ & $\begin{array}{c}\hat{0} \\
\hat{1}\end{array}$ & $\begin{array}{l}1 \\
\delta \\
\delta_{0}^{\prime}\end{array}$ & $\begin{array}{l}\text { Nh } \\
\hat{0}\end{array}$ & $\theta_{0}^{0}$ & 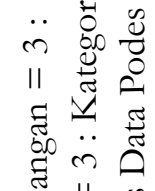 \\
\hline ص్ّ & 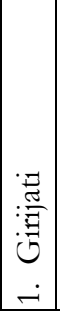 & 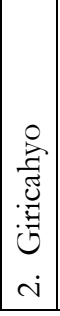 & 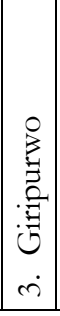 & 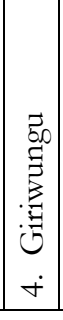 & 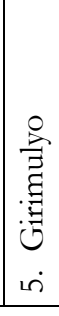 & 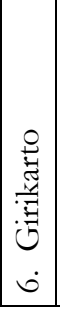 & 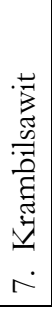 & 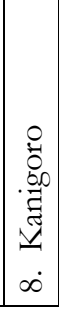 & 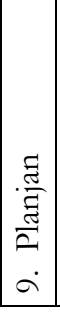 & 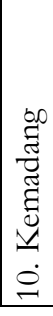 & 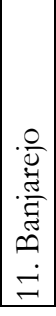 & 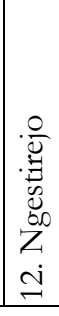 & 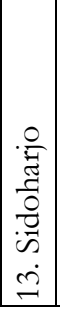 & 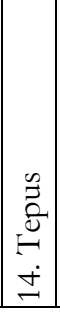 & 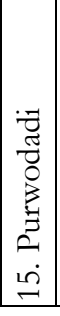 & 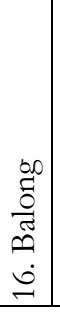 & 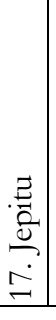 & $\begin{array}{c}\dot{b} \\
\stackrel{0}{0} \\
\stackrel{=}{F} \\
\infty \\
\stackrel{\infty}{=}\end{array}$ & $\begin{array}{c}\infty \\
0 \\
0 \\
0 \\
2 \\
2 \\
0 \\
2\end{array}$ & 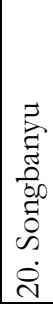 & 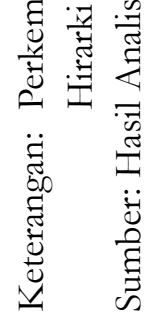 \\
\hline
\end{tabular}


(Panggang dan Kecamatan Purwosari; Paliyan dan Saptosari; Tepus dan Tanjungsari; Rongkop dan Gerbosari); telah berakibat pada pertambahan jumlah bangunan perkantoran dan fasilitas jasa, maupun bangunan rumah permanen di perdesaan pesisir. Selain itu, pengembangan beberapa obyek wisata dan perikanan laut beserta fasilitasnya di beberapa desa telah diikuti oleh peningkatan jumlah bangunan rumah permanen penduduk di setiap desa maupun kualitas penerangan.

Sebagian besar desa pesisir sebagai daerah asal migran yang relatif kritis secara fisik, justru mampu meningkatkan jumlah dan kualitas bangunan rumah di daerah asal. Secara umum sebagian besar migran baik yang kembali ke kampung halaman, maupun yang masih tinggal di perkotaan di Pulau Jawa dan di luar Jawa; cenderung membangun rumah tempat tinggal di kampung asal mereka, dengan meningkatkan kualitas fisik bangunan rumah, ataupun membangun rumah baru dengan kualitas fisik bangunan rumah permanen.

\section{Perubahan Fasilitas Permukiman Desa Pesisir}

Jumlah fasilitas fisik pelengkap suatu permukiman sangat menentukan luas lahan permukiman. Perubahan jumlah unit fasilitas permukiman antara dua periode tahun 1996 dan 2003 mencakup perubahan fasilitas ekonomi dan sosial kebudayaan. Hasil penelitian ini menunjukkan, bahwa selama tahun 1996 hingga 2003 peningkatan ketersediaan fasilitas ekonomi baru 1,4 persen. Secara keruangan peningkatan ketersediaan fasilitas ekonomi tertinggi terjadi di Desa Balong (3,03\%), sedangkan yang terendah di Desa Songbanyu $(0,03 \%)$. Artinya, bahwa perubahan ketersediaan fasilitas ekonomi untuk mendukung per- kembangan permukiman relatif kecil. Beberapa desa pesisir yang menjadi pusat pemerintahan kecamatan atau dekat obyek-obyek wisata, memiliki tingkat ketersediaan fasilitas ekonomi lebih tinggi dari pada desa lainnya. Namun demikian, peningkatan ketersediaan fasilitas ekonomi di desa-desa tersebut relatif rendah. Hal itu disebabkan sejak tahun 1996 ketersediaan fasilitas memang lebih tinggi dari pada beberapa desa pesisir lainnya.

Peningkatan ketersediaan fasilitas sosial dan kebudayaan secara keruangan, tertinggi di Desa Purwodadi (4,3\%), sedangkan peningkatan yang terendah terjadi di Desa Tileng $(0,21 \%)$. Hal itu berkaitann dengan pengembangan pusat kegiatan sosial dan kebudayaan yang juga berpengaruh terhadap penggunaan tenaga listrik antar desa selama tahun 1996-2003. Selama periode tersebut peningkatan pengguna tenaga listrik meningkat dari 50,79 persen menjadi 61,85 persen rumahtangga $(11,06 \%)$. Namun demikian proporsi rumahtangga pengguna tenaga listrik di beberapa desa ada yang mengalami penurunan. Hal ini disebabkan beberapa warga masyarakat pengguna tenaga listrik illegal pada tahun 1996 tercatat sebagai pelanggan listrik, namun setelah penertiban pengguna tenaga listrik yang tercatat tahun 2003 makin sedikit.

Dalam kaitannya dengan berbagai fasilitas di setiap desa ini di dalamnya terdapat fasilitas pendukung aktifitas pariwisata pantai dan karst. Peningkatan pemanfaatan kawasan pantai dan karst sebagai obyek pariwisata, di samping perikanan laut mendorong perkembangan permukiman pesisir. Peningkatan ketersediaan fasilitas ini merupakan salah satu indikator peningkatan budaya masyarakat, 
yang mampu menunjukkan tingkat kemajuan kehidupan secara umum di setiap desa pesisir tersebut.

\section{Persebaran Perubahan Permukiman Wilayah Pesisir}

Indikator perkembangan permukiman antara lain perubahan luas pekarangan, jumlah bangunan rumah, proporsi rumahtangga pengguna listrik, ketersediaan fasilitas ekonomi, dan ketersediaan fasilitas sosial budaya di setiap desa pesisir. Hasil penelitian menunjukkan bahwa perkembangan desa pesisir bervariasi. Perkembangan permukiman desa pesisir pada kategori tinggi selama tahun 1996 -2003 lebih banyak terjadi di perdesaan pesisir bagian barat, akibat pengembangan kawasan wisata Parangtritis. Di bagian timur hanya satu desa yang tingkat perkembangannya tinggi, yang sejak lama telah menjadi pusat ibukota kecamatan Tepus. Tingkat perkembangan beberapa desa pesisir kategori rendah sebagian besar berada di bagian timur (Lampiran Gambar 2.).

Semakin lengkap ketersediaan fasilitas di suatu desa pesisir, maka semakin banyak fungsi pelayanan yang disediakan, dan menunjukkan tingkat hirarki permu-kiman semakin tinggi. Pada Tabel 2. ditunjukkan juga di antara duapuluh desa pesisir, empat desa memiliki hirarki tiga, enambelas desa pada hirarki empat. Desa-desa pesisir yang memiliki hirarki tiga merupakan permukiman yang berkembang dan mampu melayani fasilitas sosial ataupun ekonomi dengan distribusi fungsi pelayanan lebih dari 25 persen, pada radius pelayanan lingkup satu kecamatan. Desa-desa pesisir lainnya (16 desa) memiliki hirarki empat, merupakan permukiman yang memiliki distribusi fungsi pelayanan kurang dari 25 persen, dengan radius pelayanan hanya pada tingkat desa.
Secara umum desa-desa pesisir yang memiliki fasilitas sosial ekonomi lebih tinggi dari pada desa-desa pesisir lainnya menduduki hirarki lebih tinggi. Meski demikian di desa hirarki lebih tinggi dari pada desa pesisir lainnya, belum tentu diikuti perkembangan secara cepat. Di antara empat desa pesisir yang memiliki hirarki 3 dari, terdapat satu desa dengan perkembangan termasuk kategori cukup. Sebaliknya, di antara lima desa yang memiliki tingkat perkembangan tinggi, terdapat dua desa dengan hirarki rendah (hirarki 4). Di samping itu, desa-desa dengan hirarki dan perkembangan permukimannya tinggi, belum tentu diikuti oleh konsentrasi penduduk yang padat.

\section{Pengaruh Faktor Wilayah terha- dap Perubahan Permukiman Desa pesisir}

Perubahan permukiman desa pesisir diukur dari gabungan nilai perubahan komponen pembentuk permukiman, baik perubahan luas pekarangan, perubahan jumlah bangunan rumah, dan perubahan jumlah bangunan rumah berpenerangan listrik. Hasil penelitian (Tabel 3.). menunjukkan bahwa tigabelas faktor wilayah secara bersama-sama berkorelasi positip kuat dengan perubahan permukiman perdesaan pesisir di Kabupaten Gungkidul ( $\mathrm{R}=0,95$; nilai $\mathrm{F}$ reg. $=2,860$; signif. $\mathrm{F}$ $=0,05)$. Maknanya, bahwa semakin tinggi nilai perubahan empatbelas faktor fisik wilayah, maka semakin tinggi nilai perubahan permukiman desa pesisir.

Besarnya sumbangan pengaruh ketigabelas faktor wilayah terhadap variasi faktor perubahan permukiman desa pesisir cukup besar, yakni 90,3 persen $\left(\mathrm{R}^{2}=\right.$ 0,903). Kesimpulannya, bahwa terjadinya variasi perubahan permukiman desa pesisir di Kabupaten Gunungkidul, sebesar 90,3 
Tabel 3. Koefisien Korelasi antara Empatbelas Faktor Wilayah dengan Perubahan Permukiman Desa Pesisir Kabupaten Gunungkidul

\begin{tabular}{|l|c|c|l|l|l|l|l|l|}
\hline \multicolumn{1}{|c|}{$\mathrm{R}$} & $\mathrm{R}^{2}$ & $\begin{array}{c}\mathrm{R}^{2} \text { Terse- } \\
\text { suaikan }\end{array}$ & $\begin{array}{c}\text { Simpangan } \\
\text { baku }\end{array}$ & $\begin{array}{c}\text { Perubah- } \\
\text { an } \mathrm{R}^{2}\end{array}$ & $\begin{array}{c}\text { Perubah- } \\
\text { an } \mathrm{F}\end{array}$ & $\mathrm{Db}$ & $\mathrm{Df} 2$ & $\begin{array}{c}\text { Perubahan } \\
\text { Signif. } \mathrm{F}\end{array}$ \\
\hline 0,950 & 0,903 & 0,587 & 65,1687 & 0,903 & 2,860 & 16 & 4 & 0,05 \\
\hline Anova \\
\hline Model a
\end{tabular}

Sumber: Diolah dari BPS, 1996; 2003.

persen dipengaruhi oleh variasi faktor (1) tingkat aksesebilitas, (2) rata-rata tinggi tempat, (3) rata-rata curah hujan tahunan, (4) jumlah sumur, (5) proporsi luas lahan pertanian, (6) perubahan persentase luas lahan kritis, (7) perubahan fasilitas ekonomi, (8) perubahan fasilitas sosial, (9) kepadatan penduduk, (10) kepadatan rumahtangga, (11) pertumbuhan jumlah penduduk, (12) pertumbuhan jumlah rumahtangga, dan (13) perubahan persentase jumlah rumahtangga petani. Sisanya, sebesar 9,7 persen diduga dipengaruhi faktor wilayah lainnya, baik kondisi fisik seperti geologi, jenis tanah dan kebijakan pemerintah di daerah penelitian.

Di antara ketiga belas faktor wilayah, yang berpengaruh secara signifikan terhadap perubahan permukiman desa pesisir hanya lima faktor (Tabel 4.). Urutan besarnya pengaruh setiap faktor dari yang paling besar adalah tinggi tempat tempat $($ Beta $=-1,536 ; \mathrm{T}=-4,222 ;$ Sig. $\mathrm{T}=0,013)$; jumlah sumur $($ Beta $=2,794 ; \mathrm{T}=4,086$; Sig. $\mathrm{T}=0,015)$; proporsi luas lahan pertanian $($ Beta $=1,594 ; \mathrm{T}=3,337$; Sig. $\mathrm{T}=0,029)$; kepadatan rumahtangga $($ Beta $=2,138 ; \mathrm{T}$ $=3,104$; Sig. $\mathrm{T}=0,036)$; dan kepadatan penduduk $($ Beta $=1,320 ; \mathrm{T}=2,939$; Sig. $\mathrm{T}$ $=0,042)$. Dengan demikian dapat ditarik beberapa makna konklusif bahwa:

a. Semakin besar ketinggian tempat maka perubahan permukiman desa pesisir semakin rendah, dalam arti perkembangan permukiman desa pesisir lebih dominan di daerah-daerah dengan ketinggian rendah.

b. Semakin besar jumlah keberadaan sumur di suatu desa pesisir, maka perubahan permukiman desa pesisir semakin meningkat, dalam arti perkembangan permukiman desa pesisir lebih dominan di daerah-daerah yang yang mudah memperoleh airtanah.

c. Semakin besar proporsi luas lahan pertanian di suatu desa pesisir, maka perubahan permukiman desa pesisir semakin meningkat, dalam arti perkembangan permukiman desa pesisir lebih dominan di daerah-daerah yang lahan pertanianya yang luas. 
d. Semakin besar kepadatan rumahtangga penduduk di suatu desa pesisir, maka perubahan permukiman desa pesisir semakin meningkat, dalam arti perkembangan permukiman desa pesisir lebih dominan di daerah-daerah dengan kepadatan rumahtangga yang tinggi.

e. Semakin besar kepadatan penduduk di suatu desa pesisir, maka perubahan permukiman desa pesisir semakin meningkat, dalam arti perkembangan permukiman desa pesisir lebih dominan di daerah-daerah yang berpenduduk padat.

\section{KESIMPULAN DAN SARAN}

1. Perkembangan permukiman desa pesisir baik ditinjau dari luas lahan, jumlah bangunan rumah, maupun jumlah fasilitas permukiman secara keruangan bervariasi. Perkembangan permukiman desa pesisir pada kategori tinggi, lebih banyak terjadi di perdesaan pesisir yang berdekatan ataupun berfungsi sebagai obyek wisata, dan atau berfungsi sebagai pusat kegiatan pelayanan pemerintahan. Hal ini berkaitan dengan kelengkapan fisilitas sosial ekonomi mapun fasilitas sosial budaya. Oleh karena itu dalam pengembangan permukiman daerah ini, perlu diprioritaskan pada desa-desa pesisir yang berlokasi relatif jauh dari obyek wisata maupun pusat pemerintahan, sehingga pembangunan lebih merata sesuai dengan masalah yang dihadapi dan kebutuhan penduduk setempat.

Tabel 4. Koefisien Regresi Setiap Faktor Wilayah yang Berpengaruh terhadap Perubahan Permukiman Desa Pesisir Kabupaten Gunungkidul

\begin{tabular}{|l|r|r|r|r|r|}
\hline \multirow{2}{*}{ Model b } & \multicolumn{2}{|c|}{ Koef. Reg. tdk Terbakukan } & \multicolumn{1}{c|}{$\begin{array}{c}\text { Koef. Reg. } \\
\text { Terbakukan }\end{array}$} & \multirow{2}{*}{ T } & \multirow{2}{*}{ Sig. T } \\
\cline { 2 - 3 } & \multicolumn{1}{|c|}{$\mathrm{B}$} & Simpangan Baku & \multicolumn{1}{c|}{ Beta } & & \\
\hline KONSTANTA & $-349,442$ & 565,762 & &,- 618 & 0,570 \\
\hline AKSES & 36,011 & 30,957 & 0,487 & 1,163 & 0,309 \\
\hline TINGGI TEMP & $\mathbf{- 1 , 6 7 2}$ & $\mathbf{0 , 3 9 6}$ & $\mathbf{- 1 , 5 3 6}$ & $\mathbf{- 4 , 2 2 2}$ & $\mathbf{0 , 0 1 3}$ \\
\hline HUJAN & 0,248 & 0,103 & 0,942 & 2,411 & 0,073 \\
\hline SUMUR & $\mathbf{3 9 , 6 6 2}$ & $\mathbf{9 , 7 0 6}$ & $\mathbf{2 , 7 9 4}$ & $\mathbf{4 , 0 8 6}$ & $\mathbf{0 , 0 1 5}$ \\
\hline \%LHN PERT & $\mathbf{9 , 6 4 4 E - 0 2}$ & $\mathbf{0 , 0 2 9}$ & $\mathbf{1 , 5 9 4}$ & $\mathbf{3 , 3 3 7}$ & $\mathbf{0 , 0 2 9}$ \\
\hline \%LHN KRITIS & $-4,747 E-02$ & 0,028 & $-0,605$ & $-1,672$ & 0,170 \\
\hline \%PERFASEK & -0388 & 0,206 & $-0,374$ & $-1,882$ & 0,133 \\
\hline \%PERFASOS & $-1,009$ & 0,484 & $-1,011$ & $-2,085$ & 0,105 \\
\hline KPDT PEND & $\mathbf{1 , 6 6 6}$ & $\mathbf{0 , 5 6 7}$ & $\mathbf{1 , 3 2 0}$ & $\mathbf{2 , 9 3 9}$ & $\mathbf{0 , 0 4 2}$ \\
\hline KPDT RT & $\mathbf{1 2 , 7 7 9}$ & $\mathbf{4 , 1 1 8}$ & $\mathbf{2 , 1 3 8}$ & $\mathbf{3 , 1 0 4}$ & $\mathbf{0 , 0 3 6}$ \\
\hline PERTAM PEND & 0,306 & 0,171 & 0,706 & 1,794 & 0,147 \\
\hline PERTAM RT & 0,119 & 0,160 & 0,221 & 0,747 & 0,496 \\
\hline \%RT TANI & 1,367 & 3,942 & 0,081 & 0,347 & 0,746 \\
\hline Variable terikat: PERUBAHAN PERMUK & & & \\
\hline
\end{tabular}

Sumber: Diolah dari BPS, 1996; 2003. 
2. Semakin lengkap ketersediaan fasilitas di suatu desa pesisir, maka semakin banyak fungsi pelayanan yang tersedia, sehingga tingkat hirarki permukiman semakin tinggi. Secara hirarkis sebagian besar jumlah desa pesisir masih pada tingkat hirarki empat, sedangkan sebagian kecil jumlah desa pesisir pada hirarki tiga. Artinya pola perkembangan permukiman desa pesisir belum terjadi secara maksimal, sehingga untuk pengembangan lebih lanjut perlu ditingkatkan jumlah fasilitas fisik untuk kegiatan ekonomi maupun unutk kegiatan sosial budaya masyarakat.

3. Perkembangan permukiman desa pesisir di pegunungan karst sangat ditentukan oleh komponen fisik wilayah, terutama ketinggian tempat, ketersediaan air, dan ketersediaan luas lahan untuk pertanian. Di samping itu, perkembangan ditentukan oleh kepadatan rumah tangga dan kepadatan penduduk, yang mencerminkan kepadatan bangunan fisik rumah tempat tinggal. Dengan demikian disarankan untuk pengembangan daerah perdesaan pesisir perlu diprioritaskan pada daerah yang relatif datar, dengan ketersediaan air dan lahan usaha untuk pertanian yang mudah diperoleh. Harapannya penduduk desa pesisir dapat bermukim dengan 'krasan' sehingga tidak terjadi depopulasi.

\section{DAFTAR PUSTAKA}

BPS. 1996. Potensi Desa Daerah Istimewa Yogyakarta Tahun 1996. Jakarta: Badan Pusat Statistik.

BPS. 2003. Potensi Desa Daerah Istimewa YogyakartaTahun 2003. Jakarta: Badan Pusat Statistik.

BPS. Kab. Gunungkidul. 2004. Kabupaten Gunungkidul Dalam Angka. Wonosari: BPS. Kabupaten Gunungkidul.

Dirjen. Perumahan dan Permukiman. 2002. Repeta 2003 Departemen Permukiman Dan Prasarana Wilayah. Jakarta: Direktorat Jendral Perumahan dan Permukiman.

Junghun, A.M. 1857. Java: It's Form, Vegetation Cover and Inner Architecture. Germany: Leipig.

Manning, E.W. and Sweet, M.F. 1993. Environmental Evaluation: Apractical Means of Relating Biophysical Functions to Socioeconomic Values. Canada: Foundation for International Training. Don Mils, Ontario.

Marwasta, Djaka. 2004. "Kajian Agihan Spasial Fasilitas dan Utilitas Perkotaan dan Pengaruhnya terhadap Pola Permukiman di Kota Surakarta". Forum Geografi, Vol. 18, No. 1, Juli 2004. Hlm 1-13.

Mather, A.S. 1986. Land Use. Hongkong: Longman Group United Kingdom Limited.

McDonald \& Partners. 1984. Greater Yogyakarta Groundwater Resources Study, Vol 1 and Vol 3 c: Main Report. Yogyakarta: Directorate General of Water Resources Development Project (P2AT). 
Mut'ali, Lutfi. 2003. Studi Penentuan Desa-desa Pusat Pertumbuhan di Propinsi DI Yogyakarta, Majalah Geografi Indonesia, Vol 17, No 1, Maret 2003. Yogyakarta: Fak Geografi UGM. Hal: 33-51.

Nibbering. J.W. 1990. Deforestation in the Gunungkidul, Some Historical Evidentce, Text Presented at the Faculty of Forestry UGM. Yogyakarta: Fak. Kehutanan UGM.

Pascione, Michael. 1984. Rural Geography. London: Harper \& Row, Publisher.

Raharjo, Noorhadi. 2003. Sebaran Tipe Pantai dan Karakteristik Lingkungan di Pantai Selatan Jawa, Majalah Geografi Indonesia, Vol 17, No 2, September 2003. Yogyakarta: Fak Geografi UGM. Hal: 129-145.

Ritohardoyo, Su. 1991. Pengantar Perencanaan Penggunaan Lahan. Bahan Kuliah Penggunaan Lahan. Yogyakarta: Fakultas Geografi UGM.

Ritohardoyo, Su. 2002. Perubahan Pekerjaan dari Petani ke Nelayan (Kasus Perdesaan Pantai Kabupaten Gunungkidul), Forum Geografi, Vol 16, No 1., Juli 2007. Surakarta: Fakultas Geografi UMS.

Riyadi, Dodi Slamet. 2000. Konsep Dasar Penataan Ruang Wilayah Perdesaan, dalam Pengembangan Wilayah Perdesaan dan Kawasan Tertentu. Jakarta: Direktorat Kebijaksanaan Teknologi untuk Pengembangan Wilayah, Badan Pengkajian dan Penerapan Teknologi.

Schmidt, F.H. and Ferguson, J.H.A. 1951. Rainfall Types Based on Wet and Dry Period Ratios for Indonesia with W.N. Guinea. Verh. 42. Jakarta: Kem. Perhu-bungan R.I.

Tim Fak.Geografi UGM. 2003. Kajian Pengelolaan dan Pengembangan Kawasan Karst di Propinsi Daerah Istimewa Yogyakarta. Yogyakarta: BAPEDALDA D.I. Yogyakarta dan Fak. Geografi UGM. 


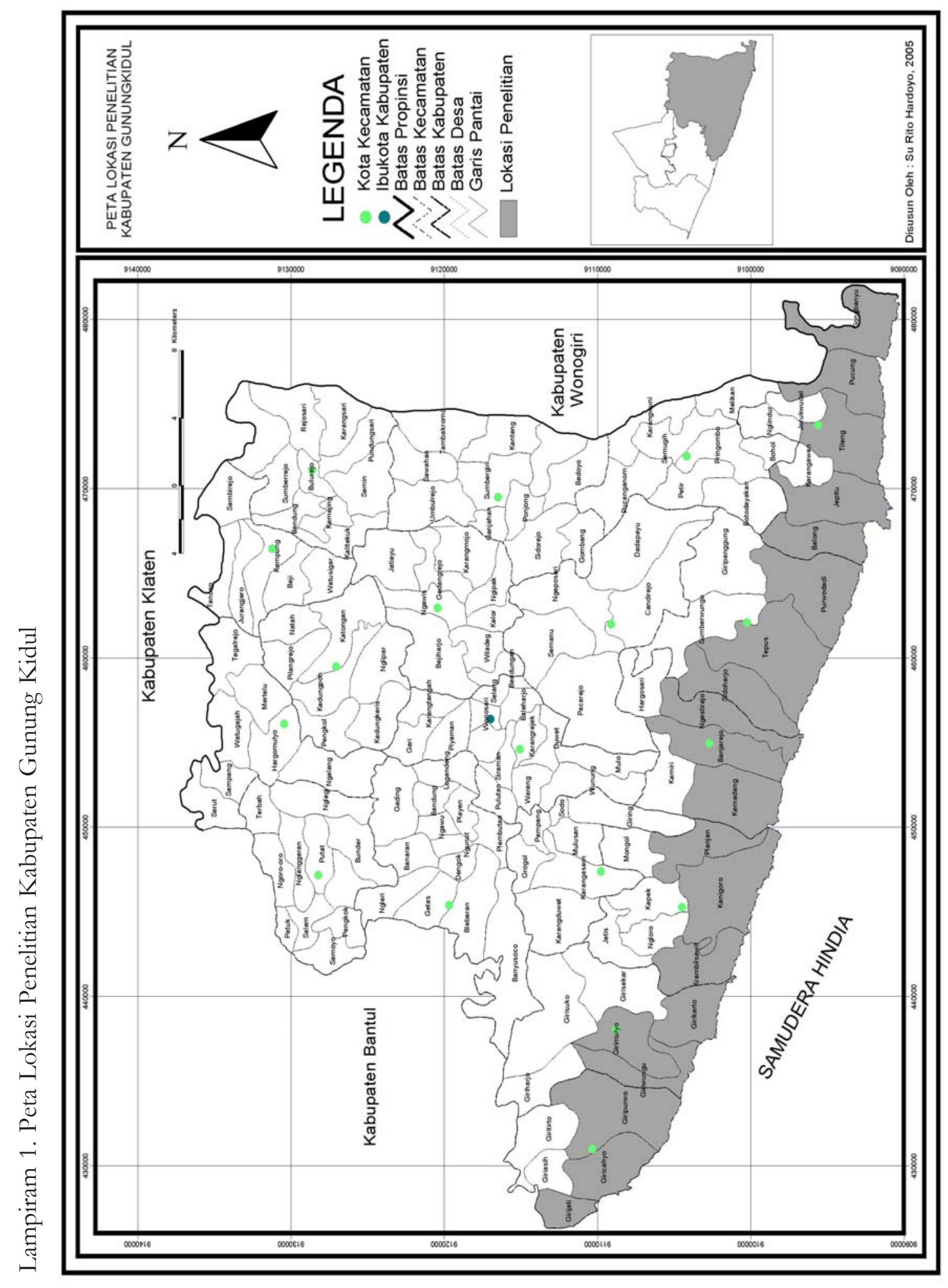

Perubahan Permukiman Perdesaan Pesisir Kabupaten Gunung Kidul ... (Su Ritohardoyo) 


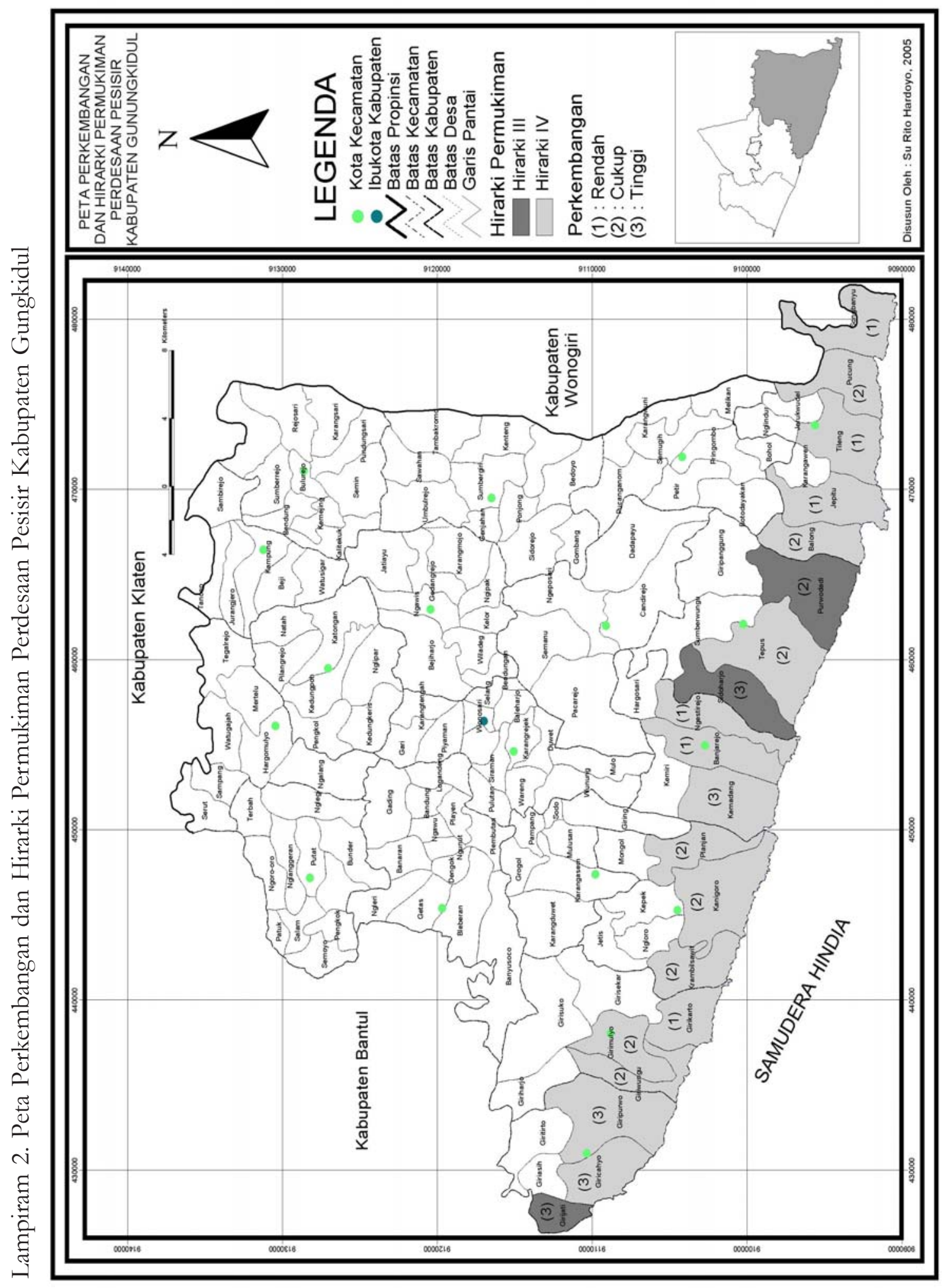

